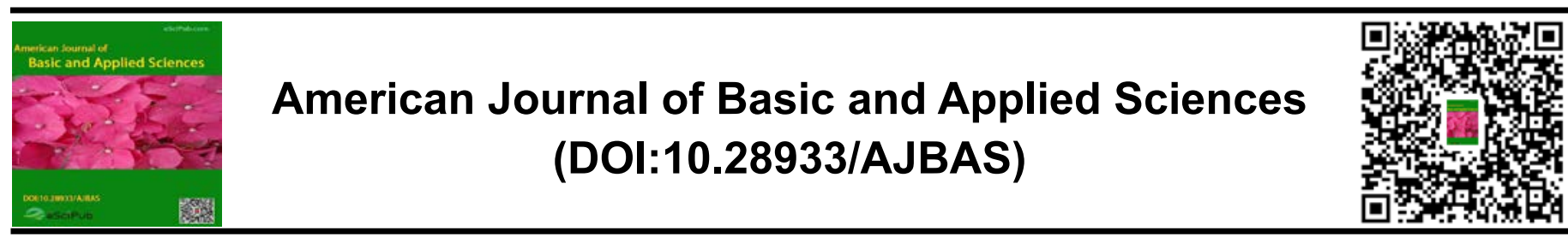

\title{
Odor evaluation scales for neoplastic wounds: an integrating review
}

\section{Santos H.N.F.L1, Souza M.A.02, Souza N.R3, Almeida G.L4, Melo J.T.S5, Santos I. C.R.V6}

1Estudante do Curso de Enfermagem pela Universidade de Pernambuco. Faculdade de Enfermagem Nossa Senhora das Graças. Recife-PE-Brasil. 2Enfermeiro Doutorando de Enfermagem do Programa de Pós-Graduação Stricto Sensu da Universidade de Pernambuco. Recife-PE-Brasil; 3,4 Enfermeiro Mestrando de Enfermagem do Programa de Pós-Graduação Stricto Sensu da Universidade de Pernambuco. Recife-PE Brasil; 5Enfermeira. Residente de Enfermagem em Traumato-Ortopedia pelo Hospital Getúlio Vargas. Recife-PE-Brasil; 6Enfermeira, Doutora, Docente do curso de Enfermagem da Universidade de Pernambuco e Coordenadora do Grupo de Pesquisa em Estomaterapia. Recife-PE-Brasil

\section{ABSTRACT}

Introduction: Cancer is a public health problem, and among patients with neoplasias, 5 to $10 \%$ will develop disease-related wounds where they affect the quality of life of the patient. Odor is the most prevalent symptomatology and requires frequent assessment to identify appropriate conduct and necessary adjustments. Objective: To verify the existence of odor evaluation instruments in neoplastic wounds. Methodology: This is an integrative review of the literature. The bibliographical survey was performed from September to October 2016 in the databases Lilacs, SciELO, IBECS and MEDLINE, with no time limit. Original articles were included in Portuguese, Spanish and English, published in full and electronically available, totaling 15 articles. Results and Discussion: Among the symptoms of neoplastic wounds, bad odor is one of the most complex to address and should be explored carefully and scientifically, for decision-making and interventions. In this research were found only scales and no instrument. Nine assessment scales were found, most of them produced by nurses, who evaluated only the intensity of the odor, and only two evaluated the distance and intensity. The most used scale was the qualitative and quantitative odor evaluation guide, designed to evaluate products and / or coverings in neoplastic wound dressings, scoring the symptom in four levels. As for validation, only the Teler scale was validated, scoring on six levels. Therefore, even in the absence of validity, the scales have been used in clinical practice, both in verifying the efficacy of the treatment for odor control and in the measurement of the symptom itself. Conclusion: The results of this study have demonstrated to date a single validated scale, pointing to the need to develop new tools in order to incorporate validated and reliable instruments into clinical practice.

Keywords: Nursing Assessment; Neoplasms; Odorants; Wounds and Injuries; Weights and Measures.

\section{${ }^{*}$ Correspondence to Author:}

Santos H.N.F.L

Estudante do Curso de Enfermagem pela Universidade de Pernambuco. Faculdade de Enfermagem Nossa Senhora das Graças. Recife-PE-Brasil

How to cite this article:

Santos H.N.F.L, Souza M.A.O, Souza N.R, Almeida G.L, Melo J.T.S5, Santos I. C.R.V. Odor evaluation scales for neoplastic wounds: an integrating review.American Journal of Basic and Applied Sciences, 2018, 1:4

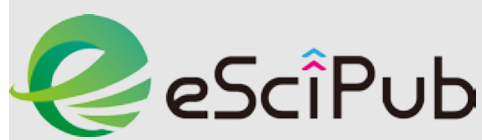

eSciPub LLC, Houston, TX USA. Website: http://escipub.com/ 